\title{
Correction to: The TRIPLE/nanoAUV initiative a technology development initiative to support astrobiological exploration of ocean worlds
}

\author{
Christoph Waldmann ${ }^{1}\left[\right.$ O Oliver Funke ${ }^{2}$
}

Published online: 24 September 2019

(c) CEAS 2019

\section{Correction to: CEAS Space Journal \\ https://doi.org/10.1007/s12567-019-00275-7}

The article "The TRIPLE/nanoAUV initiative a technology development initiative to support astrobiological exploration of ocean worlds", written by Christoph Waldmann and Oliver Funke, was originally published electronically on the publisher's internet portal (currently SpringerLink) on 10 September 2019 with open access. With the author(s)' decision to step back from Open Choice, the copyright of the article changed on September 2019 to () CEAS 2019 and the article is forthwith distributed under the terms of copyright.

The original article can be found online at https://doi.org/10.1007/ s12567-019-00275-7.

Christoph Waldmann

waldmann@marum.de

1 MARUM, Universitaet Bremen, Leobener Strasse 8, 28359 Bremen, Germany

2 German Aerospace Center (DLR), Space Administration, Koenigswinterer Strasse 522-524, 53227 Bonn, Germany 